\title{
Pseudomonas stutzeri
}

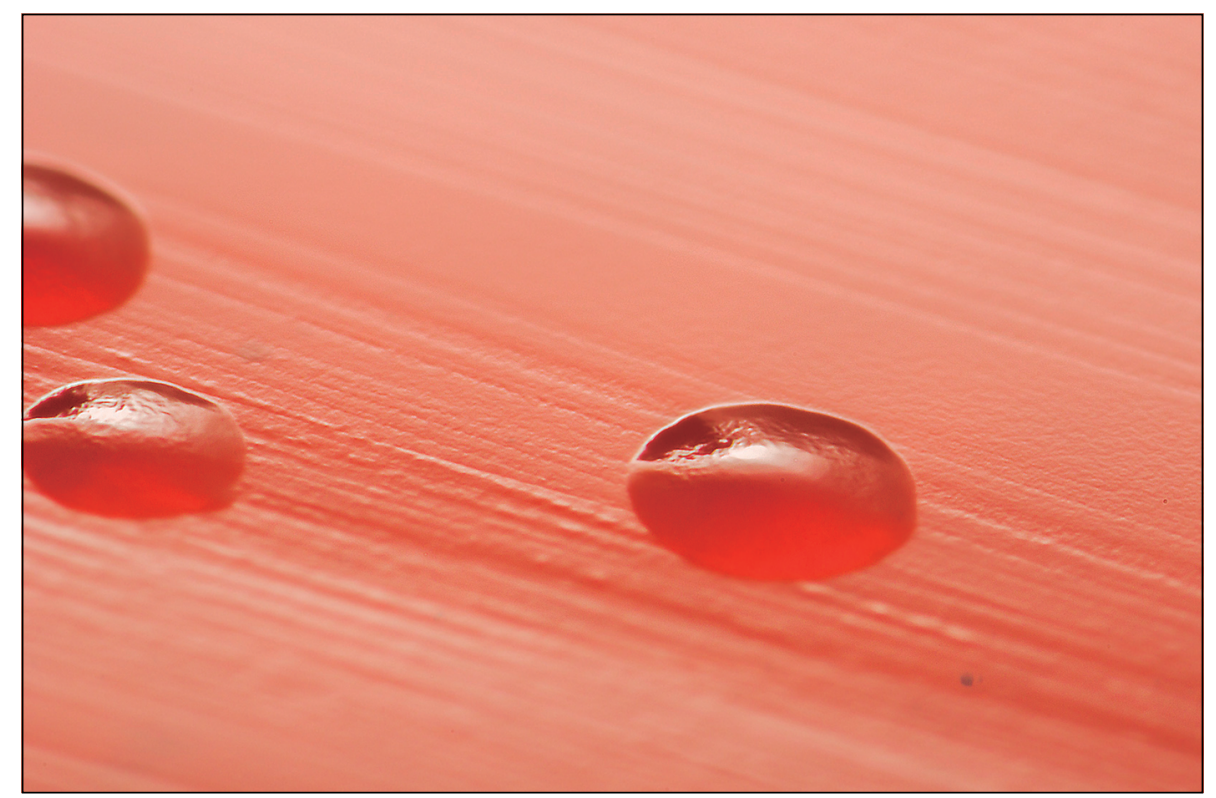

Figura 1. Morfología colonial de Pseudomonas stutzeri en agar MacConkey. Cultivo de $24 \mathrm{~h}$ incubado a $37^{\circ} \mathrm{C}$. Fotografía tomada por Jesús Luna.

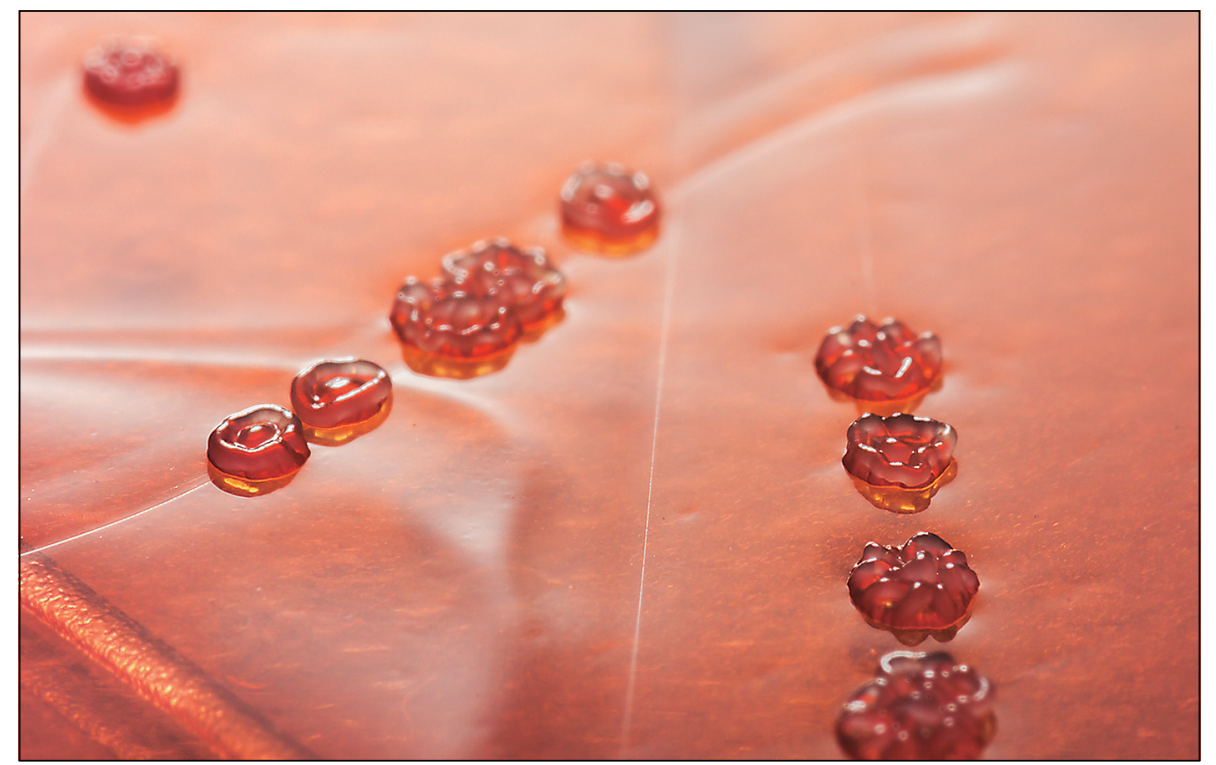

Figura 2. Morfología colonial de Pseudomonas stutzeri en agar MacConkey. Cultivo de $48 \mathrm{~h}$ incubado a $37^{\circ} \mathrm{C}$. Fotografía tomada por Jesús Luna. 


\title{
Pseudomonas stutzeri
}

Pseudomonas stutzeri es una bacteria descrita por primera vez por Burri y Stutzer dentro del género Bacillus. Posteriormente, con base en sus características fenotípicas y genéticas, se reubicó en el género Pseudomonas.

Pseudomonas stutzeri es un bacilo gramnegativo, aerobio, móvil por flagelación monótrica, oxidasa y catalasa positivas. Esta bacteria no es exigente nutricionalmente por lo que se desarrolla bien en medios de cultivos convencionales como el agar Mac Conkey. La temperatura óptima de crecimiento es de $37^{\circ} \mathrm{C} \pm 2^{\circ} \mathrm{C}$; sin embargo, se han reportado cepas capaces de crecer en temperaturas que abarcan desde $\operatorname{los} 4^{\circ} \mathrm{C}$ y hasta $\operatorname{los} 42^{\circ} \mathrm{C}$. En medios sólidos, la morfología colonial cambia con el paso del tiempo: en las primeras $24 \mathrm{~h}$ se observan colonias lisas, brillantes, convexas y con bordes enteros; posteriormente, a las $32 \mathrm{~h}$ estas colonias adquieren un aspecto crateriforme con bordes elevados y consistencia mucoide. Además, se han documentado la aparición de estructuras irregulares poligonales o zonas concéntricas.

Esta bacteria se encuentra ampliamente distribuida en el ambiente. En la literatura científica hay reportes, desde 1950, del aislamiento de $P$. stutzeri a partir de sangre, pus, piel, tejido sinovial, líquido articular y líquido cefalorraquídeo. El primer caso clínico causado por $P$. stutzeri fue descrito en 1973 implicado en un proceso de pseudo-artrosis. Desde entonces, se han notificado casos de infección asociados a bacteriemia, septicemia, endocarditis, endoftalmitis, neumonía e infecciones del tracto urinario. Esta bacteria posee una baja virulencia, y se considera un patógeno oportunista. Las cepas de origen clínico son resistentes a penicilina, cefalosporinas y $\beta$-lactámicos de amplio espectro y sensibles a las fluoroquinolonas y a algunos aminoglucósidos. Pseudomonas stutzeri produce carbapenemasas albergadas en un plásmido de $70 \mathrm{~kb}$ (DIM-1) mientras que algunos aislados tienen en el genoma un integrón clase 1-bla $\mathrm{VIIM}_{\mathrm{I}-2}$.

\section{Referencias bibliográficas}

1.- Lalucat J, Bennasar A, Bosch R, García-Valdés E, Palleroni N J. Biology of Pseudomonas stutzeri. Microbiol Mol Biol R 2006; 70: 510-47. doi: 10.1128/MMBR.00047-05.

2.- Van Niel, C. B., \& Allen, M. B. A note on Pseudomonas stutzeri. J Bacteriol 1952; 64: 413-22. PMID: 12980914.

\author{
Liliana Matías-Camacho ${ }^{1}$, Araceli Contreras-Rodríguez $z^{2}, M^{a}$ Guadalupe Aguilera-Arreola ${ }^{1}$ \\ ${ }^{1}$ Laboratorio de Bacteriología Médica. Departamento de Microbiología, Escuela Nacional de \\ Ciencias Biológicas. Instituto Politécnico Nacional. Ciudad de México, México. \\ ${ }^{2}$ Laboratorio de Microbiología General. Departamento de Microbiología, Escuela Nacional de \\ Ciencias Biológicas. Instituto Politécnico Nacional. Ciudad de México, México. \\ Correspondencia a: \\ Ma. Guadalupe Aguilera-Arreola \\ lupita_aguilera@hotmail.com; marreoag@ipn.mx
}

